\title{
A new style of Ni-Cu mineralization related to magmatic breccia pipes in a transpressional magmatic arc, Aguablanca, Spain
}

\begin{abstract}
The Aguablanca deposit represents a new style of magmatic $\mathrm{Ni} \mathrm{Cu}$ mineralization in discordant sulfide rich pyro xenitic breccia pipes. The orebody is hosted by Variscan calc alkaline diorites and gabbros which intruded during an oblique subduction/collision event. Transpressional transtensional left lateral structures facilitated the intrusion of primitive magmas to shallow depths in the crust. A two stage genetic model is proposed. In the first stage, a transitional deep magma chamber formed. The primitive magma interacted at depth with wall rocks, resulting in extensive crustal contamination, concomitant sulfide magma immiscibility and settling of orthopyroxene, clinopyrox ene and sulfide rich cumulates to form a layered magmatic complex. Geochemical and mineralogical evidence, including the virtual disappearance of olivine, heavy ${ }^{34} \mathrm{~S}$ values $(7.4 \%$ ), distinctive $\mathrm{Nd}, \mathrm{Sr}$ and $\mathrm{Pb}$ signatures, high $\mathrm{Au}$ contents, and the presence of spinel and graphite indicate a major interaction with the upper crust, probably with pyrite rich carbonaceous slates of Late Proterozoic age. The second stage was related with the emplacement of residual calc alkaline gabbroic to noritic melts and the development of an intrusive breccia containing fragments of the consolidated layered complex rocks and associated disseminated to massive sulfides.
\end{abstract}

\section{Introduction}

Magmatic Ni $\mathrm{Cu}$ deposits form a distinct style of mineralization which share several common features (Naldrett 1999): (1) location either at the base of stratiform magmatic complexes, sills or flows (e.g., Noril'sk) or as irregular bodies within the underlying feeder zones (e.g., Jinchuan, Voisey's Bay), (2) an association with olivine rich rocks (usually dunites and troctolites), and (3) a spatial rela tionship to large transcrustal faults in intraplate rifted areas. Host magmas are $\mathbf{M g}$ rich and usually of basaltic, picritic or komatitic composition (e.g., Naldrett 1981, 1999). Extensive crustal contam ination seems to be a major requirement in the formation of this style of mineralization (Lightfoot et al. 1990; Ripley et al. 1999).

In this paper we describe an unusual case of magmatic $\mathrm{Ni} \mathrm{Cu}$ mineralization at Aguablanca (SW Spain), in which synplutonic faults may have played a major role in the formation of the orebody. The style of $\mathrm{Ni} \mathrm{Cu}$ mineralization here differs from previously de scribed deposits and does not conform to current classifications (e.g., Naldrett 1981, 1999). The Aguablanca deposit is currently under economic evaluation. It was discovered after a regional geo chemical stream sediment survey which identified significant $\mathrm{Cu}$ anomalies which were related to a poorly exposed gossan with minor old workings. After systematic diamond drilling up to $700 \mathrm{~m}$ depth, provisional geological resources are about $31 \mathrm{Mt} @ 0.46 \% \mathrm{Cu}$ and $0.62 \% \mathrm{Ni}$ with $\mathrm{Co}, \mathrm{Au}$ and PGE credits. Ortega et al. (1999) report grades of up to $0.15 \mathrm{ppm} \mathrm{Au}, \mathbf{0 2} \% \mathrm{Co}$ and up to $6 \mathrm{ppm} \mathrm{Pt}+\mathrm{Pd}$ in specific zones of the orebody. Aguablanca is the only significant example of $\mathrm{Ni} \mathrm{Cu}$ mineralization in SW Europe

\section{Regional geologic setting}

The Aguablanca deposit is located in the southeastern part of the Ossa Morena Zone, one of several tectonic domains of the Iberian Massif (Quesada et al. 1991; Fig. 1). The Ossa Morena Zone was accreted to the autochthonous Iberian Terrane during Cadomian times $(620480 \mathrm{Ma})$. During the later Variscan orogeny (390 $300 \mathrm{Ma}$; Eguiluz et al. 2000), the Ossa Morena Zone acted as the overriding plate during the oblique northward subduction and collision of the exotic South Portuguese Zone with the Iberian Massif. A key feature of the Ossa Morena Zone is the existence of major WNW ESE strike slip faults which have been active throughout its evolution since Late Proterozoic imes. The oblique nature of the Variscan deformation explains many of the structural and sedimentary features, including the transection of folds by the associated cleavage (Apalategui et al. 1990), the intrusion of in termediate to acid epizonal plutons along oblique extensional structures (Castro 1985), and the formation of synorogenic trans 

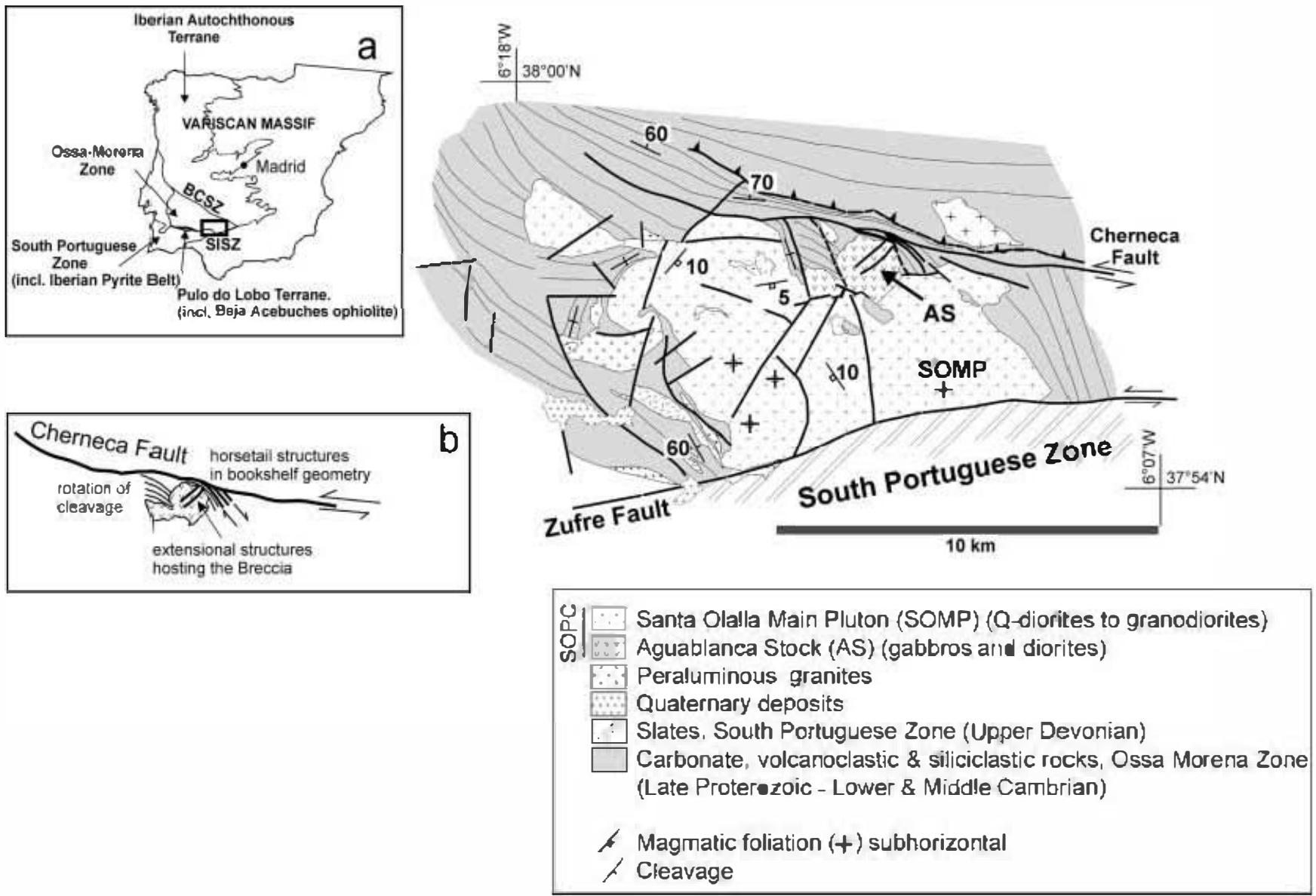

Fig. 1a, b Gedegical sketch of the Santa Olalla Plutonic Complex and Aguablanca Stock high fight ingthe structural features. The thin lines represent the main cleavage trends. a Location of the Ossa Morena Zone in the Iberian Peninsula. BCSZ Dadajez Córdoba Shear Zone; SYSZ South Ibesian Shear Zone. b Toctonic sclieme of the Aguablanca Stock

tensional basins (Gabaldón et al. 1985). Transpression was alse a key feature in the formation of the major ore deposits of SW Tber:a, including the world class massive sulfide deposits of the Iberian Pyrite Delt as well as the $\mathrm{Fe}(\mathrm{Cu})$ skams, $\mathrm{Sn}$ and $\mathrm{Hg}$ replacive minerakzation, and gold and $\mathrm{Zn} P \mathrm{P}$ veins in the Ossa Morena $Z$ one (e.g., Locutura et a l. 1996).

\section{The Santa de Olalla Plutonic Complex}

The Santa de Olalla Plutonic Complex (SOP Complex) comprises the Santa Olalla Main Pluten and the smaller Aguablanca Stock (Casquet 1984; Fig. 1). The SOP Complex is located north of the Vajiscan crustal suture which separates the Ossa Morena from the South Portuguese Zones (South Iber:an Shear Zone and its pro longat on in the Zufre Fault). Its northern boundary is close to a narrow and high angle strike skip fault, the Cherneca Fault. The rocks of the SOP Complex intruded carbonate and cale silicate rocks, metavolcanics and slates of Late Proterozoic to Early Cambrian age which unconformably verlie a several kijometer thick sequence of Late Proterozoic, altemating, pyrite bearing black slates and quartites with minor amphiboktes (Sere Negra; Quesada et al. 1987; Eguiluz et al. 26\%). The intrusion is epizonal and generated an aureole of high grade contact metamoiphism, achieving local migmatization $\left(\mathrm{T}_{\text {rax }}-7 \% 75{ }^{\circ} \mathrm{C} ; \mathbf{P}_{\text {lit }}-5\right.$ 1 kbar; Casquet 1984), superimposed on regional Vauiscan meta morphism of lower greenschist facies.

The Santa Olalla Main Pluton shows normal zoning from granodiortes and monzogranites in the core to tenalites and quartzdierites at the $\mathrm{r} \mathrm{m}$. Magmatic foliat:on, where present, is usually subhorizontal. The Aguablanca Stock represents an intru sion with morem a fic mineral composition. It is formed dominantly of modium to coarse grained amphibole biotte (quartz) diorites with stoep magmatic foliations (Diortic Unit). At its northern adge, between the diortes and the host rocks, there is a 1040 $\mathrm{m}$ thick sheet of coarse grained pyroxenitic gabbros $(\sim 65 \%)$, gabbronortes $(\sim 3 \%)$ and norites ( $5 \%$; Gabbroic Unit). Skarns are abundant in the carbenate country rocks (Casquet 1984). Ouly traces of sulfides have been reportod in these skarns.

The Santa de Olalla Plutonic Complex is one of several zoned synorogenic Variscan intrusions which occur in the central area of the Ossa Morena Zone, forming a NW SE trend (Quesada et al. 1987; Sánclez Carreter et al. 1998). The entire suite consists of I type magnet te beasing plutonic rocks dominated by biotite am phibole dierites but ranging in composit on from gabbros to granites. Magmat:c cumlulates are commen in the internal zones of some intrusions, usually as olivine rich gabbros to dunites (Pons 1982; Garcia Casquere 1995). Geochemically, the suite is defined by a high $\mathrm{K}_{2} \mathrm{O}$ calc alkaline trend (Casquet 1984; Pons 1982; Sanchez Carretere et al. 1998). The genclemistry of the SOP Complex and the influence of orustal contaminat on has boen re viewed elsewhere (Casque tet al. 1998; Tornes et al. 1999). Rb/Sr dating of the Santa Olalla Plutonic Complex gave an errorchrone -f $359+18 \mathrm{Ma}$ with a high MSWD (17.1), probably caused by the widespread hydrothermal alterat on and concomitant alterat on of or:ginal Rb/Sr values. The more likely age of intrusion is probably similar to that of the eqnivalent and nearby Durguillos Pluton (338 $+1.5 \mathrm{Ma}$; U Pb in allanite; Casquet et al. 1998). 


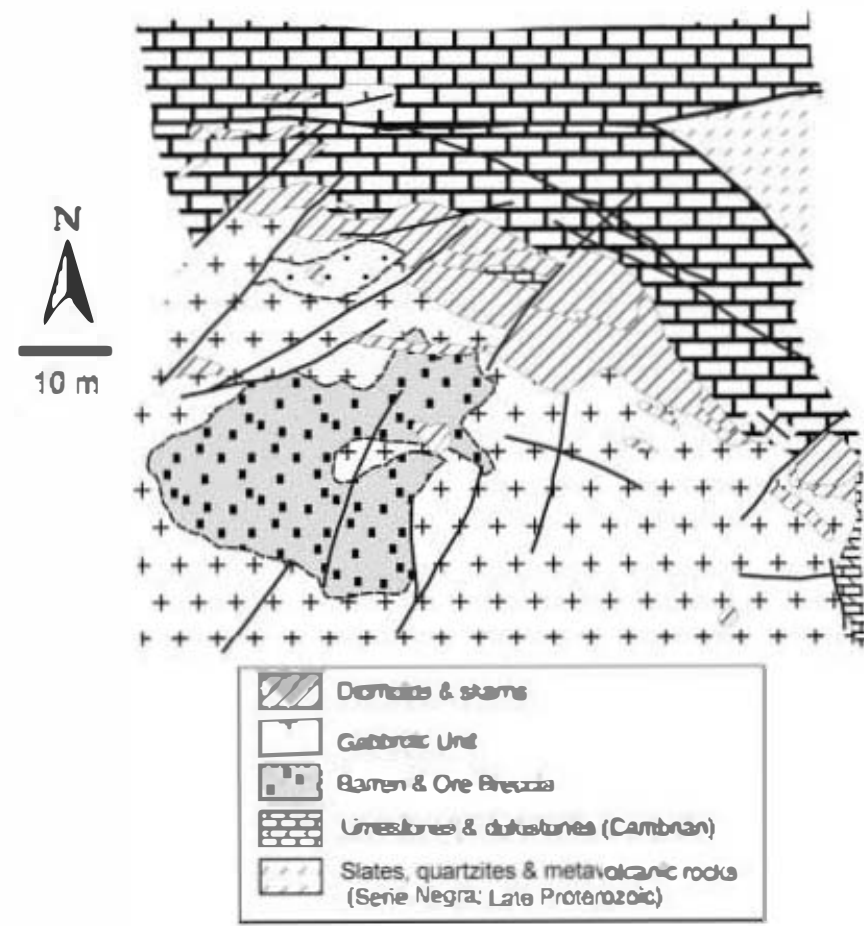

Fig. 2 Geological map of the Aguablanca orebody form a hale of weak mineralization which extends for $\sim 100 \mathrm{~m}$ away from the Ore Breccia. Maximum $\mathrm{Cu}+\mathrm{Ni}$ grades $(2.4 \% \mathrm{Cu}$, $5.4 \% \mathrm{Ni}$ ) are found in the core of the breccia pipe, but no sys temat:c lateral nor vertical variation in the $\mathrm{Cu} / \mathrm{Ni}$ rato (average $\mathrm{N} \bar{\epsilon}(\mathrm{N} i \overline{\mathrm{i}}+\mathrm{Cu})-0.6)$ has boen found with in the orebody.

Sulfides consist of early pyrrhotite intergown with pentlandite and later chalcopyrite with minor cobanite and magnetite. There is a superimposad paragenesis with coarse grained pertilandite, chakroyirte and pyrrhotite along with some cobalite and graphite, in a sequerce smitar and $\mathrm{Naldrett}$ (1987).

Al] the rocks of the Aguablanca Stock underwent subselidus hydrothermal alteration. In general, the mafic rocks are more al terod than the ultramafic rocks. Mafic minerals are replaced by clinoamphiboles of variable composition (actinofite, $\mathrm{Mg}$ horn blende and odenite pargasite), biot te phlogopite and lesser clino zoisite. Pagiodase is replacod by sericite. A second stage of hydrothermal alteration is characterized by the presence of talc, clinochore ripidolite, ealcite, llite and clay minerals. Peridotitic enclaves are replaced by serpentine, vermiculite and magetite. $K$ Ar dating suggests that hydrothermal a Mer at on took place between 325 and $307 \mathrm{Mz}$ (Casquet et al. 1998), well after the end of the magmatic activity.

The sulfides recsystalized dming hydrothemal alkeration, forming veins and mases which rephace the scrroming rocks. The seccundary sulfides are pyrithotite, Glaboypyrite pentlandite and pyrite with mackinawite and bravorte, with mimor Ag Di Pd tellu rides and ther complex minerals of the plat num group (see Lunar et al. 1997; Ortega et al. 1999).

A remarkable feature of the mineralized area is the conspicuous subvertical NE SW (N40 $55^{\circ} \mathrm{E}$ ) orientation of layering in the gabbros and of the fragments within the breccia, subparallel to some of the faults of the area (Fig. 2). The zones of major hy drothermal alteration seem alse to be controllod by these faults.

\section{The orebody}

In the NE part of the Aguablanca Stock, there is a subvertical breccia body with a pipe like morphology (Fig. 2) which has been tracod down to a depth of $\mathrm{c} .700 \mathrm{~m}$. The brocia is complex, chaotic and highly heferolithic. It comiains varinbly szed (several mm to $4 \mathrm{~m}$ across), el]posoidal cagments of fure grained orthopyroxenites, websterites, clinopyroxencites and some medium grained gabbros and gabbronorites, all showing cumula textures. Olivine bearing rocks are very scarce. The main minerals are orthopyraxene (Emb-87), clintopyroxene (diopside salite to augite) and plagioclase. The orthopyraxenites contain some inclusions of olivine ( $\left.F_{\bullet: 6-8:}\right)$ rich cumulates. $\mathrm{Mg}$ rich phlogopite and clinoampluibole eccur as intercumulus pla.ses. Al] these minerals, including olivine, have low $\mathrm{Ni}$ contents ( $<5 \%$ ppm $\mathrm{Ni}$ ). A commen aceessory phase is xene Jithic $\mathrm{Cr}$ and $\mathrm{Ni}$ poor $\mathrm{Fe}$ spinel, which oocurs in olusters within plagioclase. The breccia also includes some fragments of skam, horrufels and marble.

On the basis of the compesition of the matrix two different types of breccias can be distingursted, the Ore Breccia and Barren Breccia. The Ore Breccia bas the fragments enclosed in an urde formod sulfide rich matir Enclosed in this beccia there are is regular, meter sined ellipsoidal massive sulfide bodies which certain only some spoadic agments of silicate rocks. Massive sulfides in the Ore Breccia hest abundant, randomly oriented crystals (1 $3 \mathrm{~mm}$ in size) of bronzite $\left(\mathrm{En}_{74-8\}}\right.$ ) and diopside augite, which coalesce to form aggregates of coarse grained pyroxenites with intercumulus sulfides. The contact between the sulfides and the fragments is always sliarp, the fragments showing neither intersti tial sulfides nor reaction r.ms (Fig. 3).

The matrix of Basren Breccia is composed of coarse grainsd rocks similar to these of the Gabbroic Unit and containing only disceminated sulfides (1 $5 \mathrm{v} \cdot \mathrm{l} \%$ ). The contact betwoen the twe breccias is sharp and the Barren Brecoia orades outwards ever a short distance int the massive Gabbroic Unit which contains only minor ultramafic fragments and disseminated sulfides. The dis semirzlod sulfides in the Darren Breccia and the Gabbroic Unit

\section{Geometry of the intrusions and structural control}

Bocance the Sanka Olalla Fantonic Complex is tomsat in the southeast by the important regiomal Zaire Fajult its original - rerall geornetry remains unknossn. Igneous foliations in the Santa. Olalla Main Pluton dip gently inwards (usually between ? and $20^{\circ}$ ). The resulting concentic pattern infesred from foliation -rajector es suggests a funncl sliaped geometry, with a feeder zone to the southwest of the exposed part of the intrusion. The presence of many flat lying roof pendants visible in the area, and the herizontal a.ttitude of most of the upper contact along the adge of the pluton indicate that the top of the pluton was almost herizental. However, the structure of the Aguablanca Stock is different. Faint layering visible in the gabbros is very steep. The attitude of the contact turns from almost subvertical into gently outward alang the northwest exposure of the pluton. Thus, a belJ jar geometns writh a subvertical foeding dyke secms mere plansite, athongh the restricted nmeber of outcrops makes it dificult to oblain a precise inage of the introion. Geochemical com innity between the rocks of the Agrahlansa Stort and those of the Santa Olalla Main Pluton sugsests that the corresponding nagmas were derived from a common magma shamber at deplh (Castquet et a]. 1998).

The intrusive rocks of the area seem to have a major structural control. Both the Aguablanca Stock and the magmat:c breccia have a slape and orientation consistent with their formation along subvertical extensional zones associated with lefi. lateral shearing (Fig. 1). Other local structiral indicators, such as (1) the rotated cleavage around the pluton, and (2) the presence of antithetic (dextral) NW SE stroke slip faults with a bookshelf geometry in the eastern part of the pluton confirm such a medel. Both pull apart structures and releasing bands relatod with the curvature of the Cherneca Fault appear to have allowed the magmas to intrude at shallow crustal levels. 

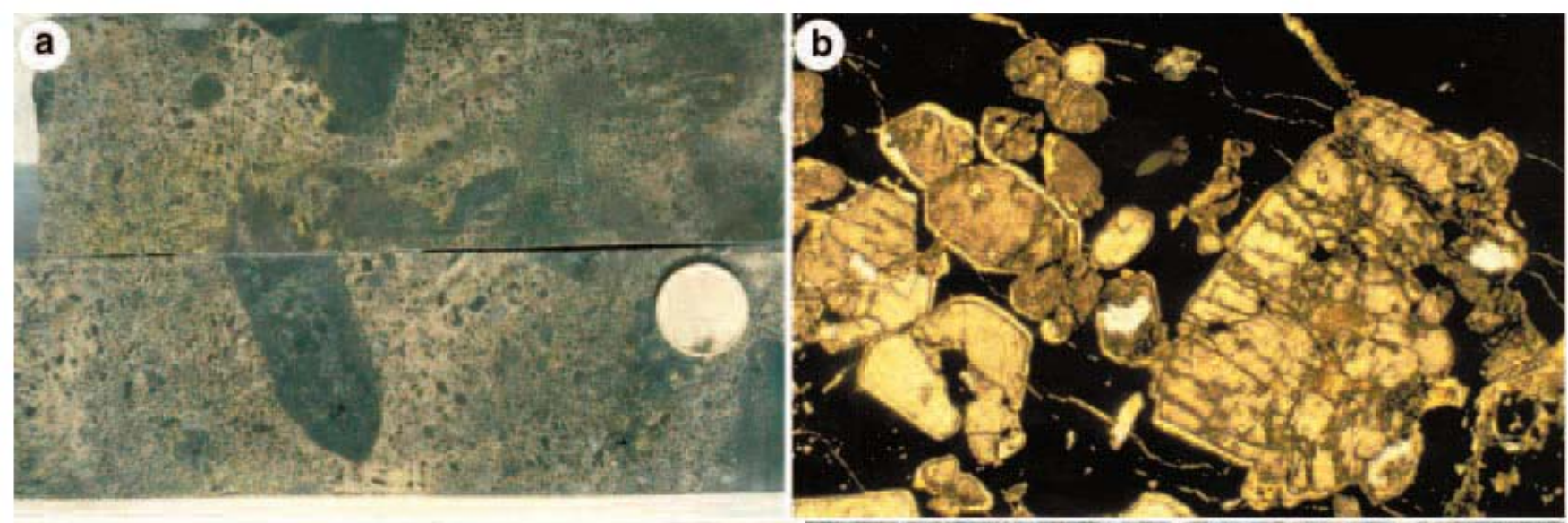

\section{c}

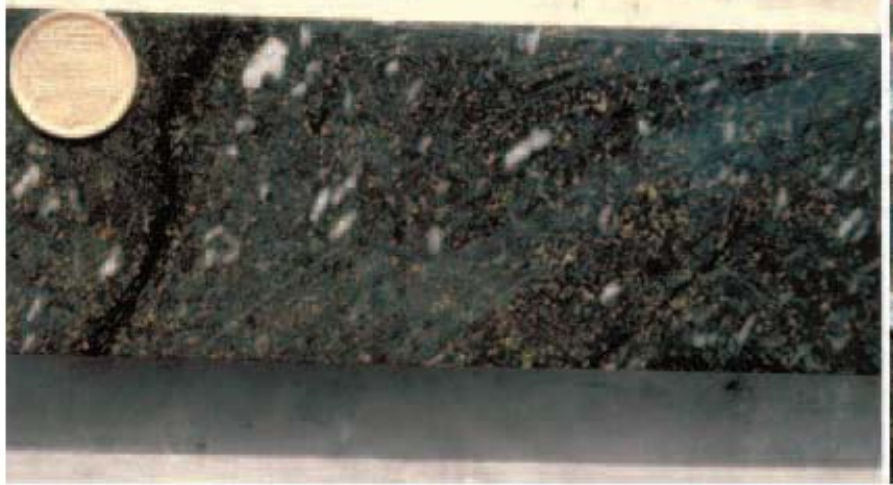

Fig. 3a d Textures of the mineraleed samples. a Semi massive ore in the ore broccia including fragments of fune grainod pyroxenites and large isolated arystals of pyroxenes with equivalent composi t:on. b Intercumulus sulfides supporting large isolated and unoriented arystals of ortho and clinopyroxere. The pyroxenes contain inclusions of biotite phlogepite and a r:m of clinoamphi boles due to late retrograde alteration. Field of view: $2.5 \mathrm{~mm}$. $c$ Gabbronorite of the Gabbroic Unit hosting disseminated miner alization. d Breccia Ore, including fragments of fune grained and barren pyroxenites suppertad by massive sulfides

Regional studies have shown that the Ossa Morena Zone ex perienced an important episedic left lateral displacement diring the Variscan Orogeny. Most of the displacement took place along the ald Cadomian suture (Badajoz Cordoba Shear Zone) but Quesada et al. (1987) and Roberts et al. (1991) have shown that significant displacement occurred aleng other WVW ESE struc tures. In this context, the Chesneca Fault probably acted as a second order, deep left lateral shear zone, favosing the format on of extensional structures and concomitant intrusion of igneous recks.

\section{Genesis of the mineralized breccia}

The association of the mineralizat on with zoned pipe like discor dant breccia bodies makes the Aguablanca orebody rather similar to the Voisey's Day deposit ( $\mathrm{L}$ et al. 2Wv). Itcould well represent a foeder conduit of an overlying pluton which now has ereded away. However, the gealogic position and the dominance of cumulate pyroxene $r$ ch fragments in the breccia may indicate that the po sition of the pipe is different posed magmatic stratiform complex. Layers of pyroxenite and

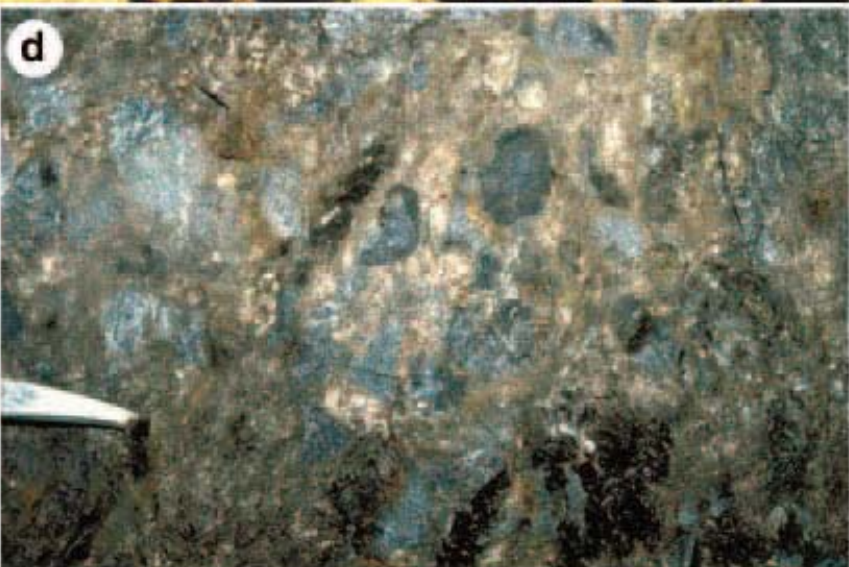

minor peridotite, gabbre and nor te, interbedded. with one or more strat:form bodies of massive sulfides, were the source of the frag ments now seen in the breccias.

Different mechanisms can explain the rupture of the stratiform magmat:c cla.mber and foumation of the breccia pipe. Simple opering of a zone of weakness related to a tensile fracture within the chamber could produce enough lateral overpressure to inject the sulfide magma inte the open space. Alternative, equally valid modells include tectoric squeering or seismic pumping

Most of the rocks in the stratifoum complex had already orys tallized when they were incespcirated in the breccia. However, the sulfides do not show any evidence of subsolidus deformat:on, indicating that their emplacement was in a plastic state, most probably as large immiscible blebs in the host gabbres. The related cearse grained pyroxene arystals could be interpreted as megaarysts trapped at depth by the moken sulfides (Arndt, personal commu nication). The temperature of injection of the brecia is corisistent with that of the intrusion of the host Gabbreic Unit and the high grade contact metamerphism. The conselidation of the breccia probably took place at temperatures above the mss solidus (near $1, N^{\circ} \mathrm{C}$ ) but below the orthe and chnopyroxere solidus (about 1,201, in ${ }^{\circ} \mathrm{C}$ ).

In the Santa Olalla Plutonic Complex, the Sr and Nd isotopic compositions suggest an evolution which can be modeled by a combination of fraction cesses (Casquet et al. 1998). The major geochemical difference be tween the Aguablanca Steck and equival t Variscan intrusions in the Ossa Merena Zone is the high ${ }^{87} \mathrm{Sr} /{ }^{86} \mathrm{Sr}_{\mathrm{i}}$ and low ${ }^{143} \mathrm{Nd} /{ }^{144} \mathrm{Nd}$. of the mafic rocks in the Aguablanea Stock, which have ${ }^{87} \mathrm{Sr}^{86} \mathrm{Sr}_{i}$ and ${ }^{143} \mathrm{Nd} /{ }^{144} \mathrm{Nd}$ i values which plot between those of the unmin eralized Variscan plutens of the area and the host metasedimentary rocks (Casquet et al. 1998; Ternos et al. 1999). These compesitions suggest that the magma assimilated sediments broadly equivalent to these hosting the Aguablarka Stock (Fig. 4). Mixing with upper orustal rocks is alse evident in the isotopic composit:ons of sulfur 




Fig. $4{ }^{143} \mathrm{Nd} /{ }^{144} \mathrm{Nd} v{ }^{87} \mathrm{Sr} /{ }^{86} \mathrm{Sr}$ ratios at $338 \mathrm{Ma}$ for igneous rocks of the Ossa Morena Zone and host Upper Proterozoic Lower Cambrian sediments and volcanic rocks. The data from the Aguablanca Stock and Santa Olalla Main Pluton plot between those of uncontaminated plutons and the host rocks (modified from Tornos et al. 1999, with data from Casquet et al. 1998)

and lead. The $\delta^{34} \mathrm{~S}$ values of the sulfides $(7.4 \pm 0.4 \% ; n=19)$ are intermediate between those of juvenile sulfur and those of the Upper Proterozoic siliciclastic sediments (7 21\%; Tornos and Ve lasco, unpublished data). The lead isotope signatures of the ore $\left({ }^{206} \mathrm{~Pb} /{ }^{204} \mathrm{~Pb}=18.2718 .43 ;{ }^{207} \mathrm{~Pb} /{ }^{204} \mathrm{~Pb}=15.6115 .65\right)$ are similar to those of the host rocks and also typical of rocks from orogenic settings with lead derived from the host rocks (Tornos et al. 1998). Additional evidence for upper crustal contamination includes the high orthopyroxene/olivine ratio of the igneous rocks, the presence of enclaves of sedimentary rocks in the Aguablanca Stock, and the abundance of spinel in the gabbros.

The commonly accepted mechanism of formation of magmatic $\mathrm{Ni} \mathrm{Cu}$ mineralisation is the incorporation of external sulfur from the host rocks via magmatic assimilation or metamorphic sulfur devolatilization (Naldrett 1999; Ripley et al. 1999). Extensive in teraction with the underlying pyritic black slates of the Serie Negra was probably the critical mechanism promoting sulfide immisci bility. These rocks have locally significant copper and gold contents (Locutura et al. 1990), and their assimilation may have been re sponsible of the relatively high gold contents of the ore $(\mathrm{Au} /$ $\mathrm{Au}_{\text {chondrite }}=5.6$ ) and the presence of graphite in the late magmatic assemblages. We propose that the enrichment of silica, sulfur and alkalis associated with the assimilation of sediments resulted in the generation of an immiscible sulfide liquid and a silica rich, chal cophile element depleted magma which afterwards crystallized to form pyroxenites at the bottom of the magmatic chamber and feeder zones. Assimilation of large quantities of slates would have increased the iron and sulfur contents of the igneous rock, pro ducing the observed low (chalcopyrite + pentlandite)/pyrrhotite ratios $(0.10 .2)$ in the ore. Naldrett (1999) has emphasized the importance of feeder zones for contamination. This author pointed out that in a conduit, the relative proportion of exposed wall rock is higher than in a magma chamber, and suggested that this leads to enhanced partial melting and assimilation of crustal rocks. The moderately high $\mathrm{Cu} /(\mathrm{Cu}+\mathrm{Ni})$ ratio of the ore $(0.40)$ indicates that the parental magma was relatively evolved ( $\mathrm{MgO}$ close to $7 \%$ ) when compared with other mafic rocks which host $\mathrm{Ni} \mathrm{Cu}$ sulfide deposits (Scoates and Mitchell 2000).
Local derivation of sulfur during skarn formation seems very unlikely. The skarns are always separated from the mineralization by barren igneous rocks. The gabbros cut across the metasomatic zoning, suggesting that the skarns formed before the magmatic mineralization. Furthermore, where the mafic rocks show a high degree of interaction with the host carbonates, the resulting rocks (endoskarns and $\mathrm{Ca}$ rich gabbros) are always barren (Casquet 1980; Tornos et al. 1999).

\section{Conclusions}

The Aguablanca ore deposit probably represents a type of igneous rock hosted $\mathrm{Ni} \mathrm{Cu}$ mineralization not described to date, related to a polyphase and syntectonic magmatic activity which led to the for mation of discordant breccia pipes. Important aspects of this de posit include the extensive crustal contamination, the strong structural control, and the evolution in a dynamic magmatic setting. The geotectonic position, in an active continental margin and as sociated with potassic calc alkaline magmatic rocks, is also unusual.

The mineralization is thought to be directly related to the Variscan transpressional tectonics in SW Iberia. In this context, extensional zones related to large and deep strike slip faults favored the episodic intrusion of primitive mafic mantle derived magmas into the upper crust. The geological and structural relationships suggest a complex two stage magmatic evolution. The first stage involved extensive assimilation of pyritic black slates in a conduit system connected with a mid crustal magma chamber. Crustal contamination resulted in the segregation of immiscible sulfides from the resulting hybrid magma. This contamination was crucial in the genesis of the deposit, as it inhibited the formation of olivine at the very early stages. The magma then rose and ponded in an overlying magma chamber. Fractional crystallization generated a stratiform magmatic complex containing mafic and ultramafic cumulates and interbedded massive sulfides, a classical magmatic $\mathrm{Ni} \mathrm{Cu}$ deposit (Fig. 5).

A second tectonic event then injected the residual melts and partially consolidated cumulates high into the crust. Partially crystallized cumulates were broken up and were forcibly injected to epizonal levels, a process probably favored by the presence of the molten sulfides. Sulfides reached the emplacement level as the matrix of the breccia but also as large massive blebs.

The Aguablanca deposit formed in a calc alkaline intrusion lo cated in a transtensional structure within a Variscan magmatic arc. Transpressional transtensional settings are now interpreted as being of major interest and are thought to control the location of a wide variety of mineral deposits, including mesothermal gold veins, epi thermal gold, volcanic and shale hosted massive sulfides, and porphyry copper districts. However, there is no previous evidence that they were implicated in the formation of magmatic $\mathrm{Ni} \mathrm{Cu}$ mineralization. $\mathrm{Ni} \mathrm{Cu}$ ores related to synorogenic plutonism are rare and only a few examples have been described previously (e.g., Vakkerlien, Thompson et al. 1980; Moxie Pluton, Thompson 1984).

The geologic setting of the Aguablanca deposit indicates that magmatic $\mathrm{Ni} \mathrm{Cu}$ deposits are not solely restricted to basaltic flows, stratiform complexes or anorthositic belts. They can also form within the more mafic rocks in active continental margin settings, the only major prerequisites for ore formation being the relation ship with major crustal faults and the existence of strong crustal contamination. If this model holds true, it can help exploration for other unpredicted breccia pipes and underlying stratiform com plexes in the Ossa Morena Zone or similar terranes. The conditions which led to the formation of the Aguablanca deposit should not be unique, and deposits of similar style may be more common than is currently recognized.

Acknowledgements We gratefully acknowledge the comments and suggestions of Noel White, Anthony Naldrett, John Thompson and Nicholas Arndt, which significantly improved the original manu script. The Consorcio Estado Español (PRESUR) Atlantic Copper is thanked for the support of this study. This work is a contribution 
Fig. 5 Conceptual geological

model for the genesis of the Aguablanca orebedy with a two stage ore forming process. FC Fractional crystallization

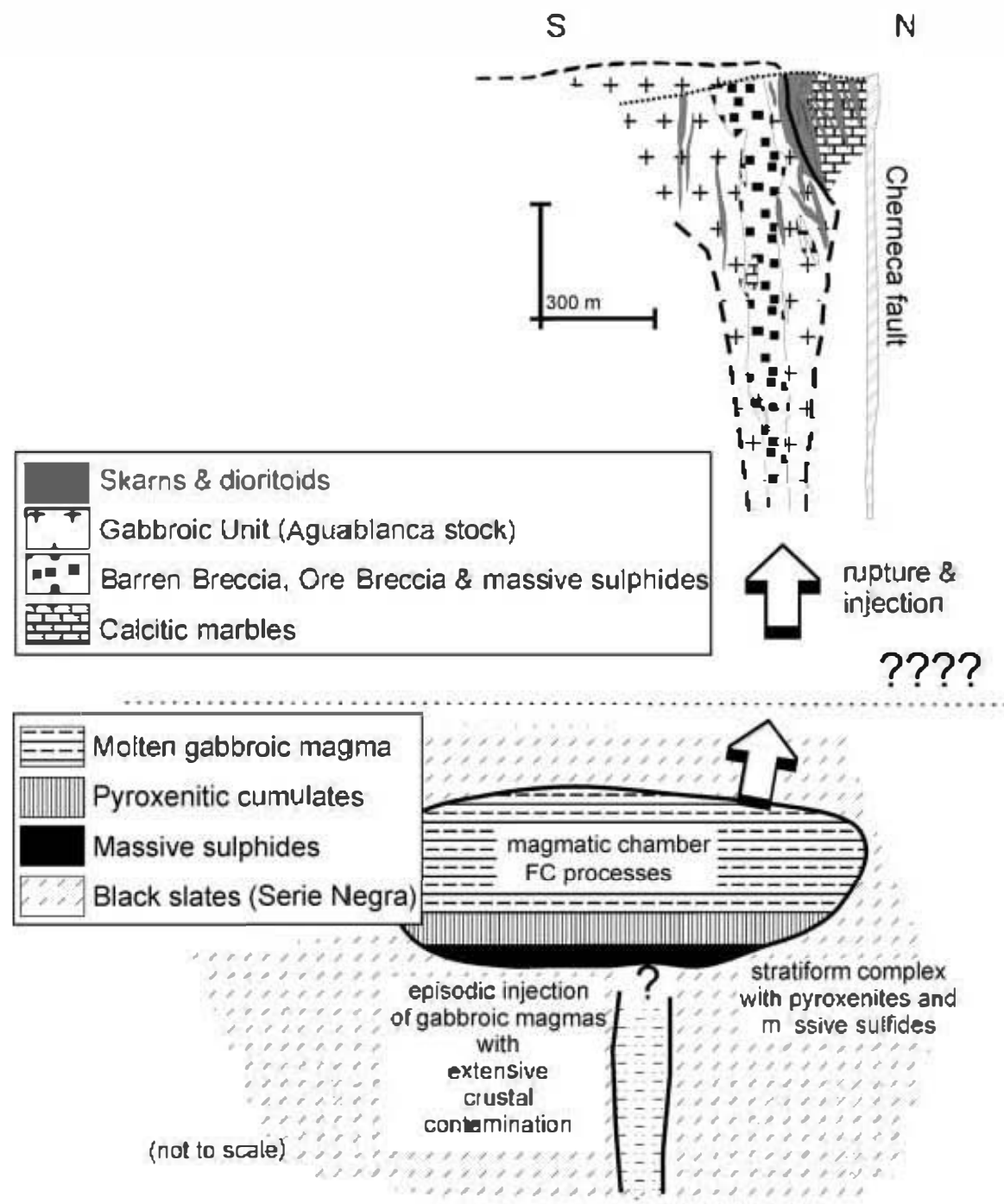

to IGCP 427 and GEODE (ESF) projects and has been funded by the Spanish DGES projects number PD96 135 and AMD 18 CO2 1. The authors are grateful to Drs Cehmann and Mekher for the review of the paper.

\section{References}

Apalategui O, Eguiluz L, Quesada C (1996) Ossa Morena Zone: Structure. In Martinez E, Dalmeyer RD (ads) Pre Mesozoic geology of Iberia. Springer, Derlin Heidelberg New York, pp 28291

Casquet C (198*) Fenómenos de endemesfism•, metamosfism• y metasımat:smo en los mármoles de la Rivera de Cala (Sierra Morena). PhD Thesis, Universidad Complutense Madrid

Casquet C, Eguiluz L, Galind• C, Tomes F, Velasce F (1998) The Aguablanca Cu NI (PGE) intraplutonic ore deposit (Extrema dura, Spain). Isotope (Sr, Nd, S) constraints on the source and evolution of magmas and sulfides. Gengaceta 24:71 74

Castro A (1985) The Central Extremadura batholith. Geotectonic implications (European Hercynan Belt). An outline. Tectono pliysics 12:57 68

Ebel DS, Naldrett AJ (1997) Crystalfization of sulfide liquids and the interpretation of ore composition. Can J Earth Sa $34: 352365$
Eguiluz L, Gil Ibarguclıi $\Pi$, Abales D, Apraiz A (200) Superpesed hercynian and cadomian oregenic cycles in the Ossa Morena Zone and related areas of the Iberian Massif. Geol Soc Am Dull 112:1398 1413

Gabaldón V, Gaırote A, Quesada C (1985) El Carbonifero Inferior del Norte de la Zona de Ossa Morena (SW de España). Proc 1th Congr Geologia Carbenifere, IGME, Madrid, pp 173185

Garcia Casquere JL (1995) Intrusión múltiple y cuerpos igneos politipicos: 1 Complejo Igneo de Durgullos del Cerro, un maciz dioritic zonad en el basamente varisce de la Peninsula Iberica. Dol Geol Minere 1 6:379 398

Li C, Lightfoot PC, Amelin Y, Naldrett AJ (200) Contrasting petrological and geocliemical relat onships in the Voisey's Day and Mushuau intrusions, Labrador, Canada: implications for ore genesis. Econ Geol 95:771 799

Lightfoot PC, Naldrett AJ, Gerbachev, NS, Dollerty W, Fed renke VA (1990) Geochemistry of the Siberian Trap of the Norl]'sk area, USSR, with implicat ons for the relative contri butions of orust and mantle to fleed basalt magmat: $\mathrm{sm}$. Centrib Mineral Petrol 104:631 644

locutura J, Tornes F, Florido P, Baeza L (1998) Ossa Morena Zone: metallogeny. In: Martinez E, Dallmeyer RD (ads) Pre Mesøzoic Geology of Iberia. Springer, Derkn Heidelberg New York, pp 321332

Lunar R, Garcia Palomero F, Ortega L, Sierra J, Moreno T, Prichard $H$ (1997) Ni Cu (PGM) minerakzation asseciated with mafic and ultramafic rocks: the recently discovered 
Aguablanca ore deposit, SW Spain. In: Papunen H (ed) Min eral deposits: research and exploration. Balkema, Rotterdam, pp 463466

Naldrett AJ (1981) Nickel sulfide deposits: classification, compo sition and genesis. In: Skinner B (ed) Economic geology, 75th Anniversary Volume, pp 628685

Naldrett AJ (1999) World class Ni Cu PGE deposits: key factors in their genesis. Miner Deposita 34:227 240

Ortega L, Moreno T, Lunar R, Prichard H, Sierra J, Bomati Fisher P, García Palomero F (1999) Minerales del grupo del platino y fases asociadas en el depósito de Ni Cu (EGP) de Aguablanca, SW España. Geogaceta 25:155 158

Pons J (1982) Un modèle d'évolution de complexes plutoniques: gabbros et granitoides de la Sierra Morena occidentale (Es pagne). PhD Thesis, Doc Trav Lab Géologie Pétrologie Uni versité $P$ Sabatier, Toulouse

Quesada C, Florido P, Gumiel P, Osborne J, Larrea F, Baeza L, Ortega C, Tornos F, Sigüenza J (1987) Mapa geológico minero de Extremadura. Junta de Extremadura, Dir Gen Industria, Energía y Minas

Quesada C, Bellido F, Dallmeyer RD, Gil Ibarguchi I, Oliveira TJ, Perez Estaun A, Ribeiro A (1991) Terranes within the Iberian Massif: correlations with West Africa sequences. In: Dalhneyer RD (ed) The West African orogens and circum Atlantic correlations. Springer, Berlin Heidelberg New York, pp 712746

Ripley EM, Lambert DD, Frick LR (1999) Re Os, Sm Nd and Pb isotopic constraints on mantle and crustal contribution to magmatic sulfide mineralization in the Duluth Complex. Geo chim Cosmochim Acta 62:3349 3365

Roberts S, Sanderson DJ, Dee S, Gumiel P (1991) Tectonic setting and fluid evolution of auriferous quartz veins from La Codo sera area, western Spain. Econ Geol 86:1012 1022

Sánchez Carretero R, Eguiluz L, Pascual E, Carracedo M (1990) Ossa Morena Zone: igneous rocks. In: Martinez E, Dallmeyer RD (eds) Pre Mesozoic geology of Iberia. Springer, Berlin Heidelberg New York, pp 292313

Scoates JS, Mitchell JN (2000) The evolution of troctolitic and high Al basaltic magmas in the Proterozoic anorthosite plutonic suites and implications for the Voisey's Bay massive $\mathrm{Ni} \mathrm{Cu}$ sulfide deposit. Econ Geol 95:677 702

Thompson JFH (1984) Acadian synorogenic mafic in rusions in the Maine Appalachians. Am J Sci 284:462 483

Thompson JFH, Nixon F, Siverstein R (1980) The geology of the Vakkerlien nickel prospect, Kvikne, Norway. Bull Geol Soc Finland 52:3 21

Tornos F, Chiaradia M, Fontboté L (1998) La geoquímica isotópica del plomo en las mineralizaciones de la Zona de Ossa Morena (ZOM): implicaciones metalogenéticas y geotectónicas. Bol Soc Esp Mineral 21 A:206 207

Tornos F, Casquet C, Galindo C, Canales A, Velasco F (1999) The genesis of the Variscan ultramafic hosted magmatic $\mathrm{Cu} \mathrm{Ni}$ de posit of Aguablanca, SW Spain. In: Stanley CJ et al. (eds) Mineral deposits: processes to processing. Balkema, Rotterdam, pp 795798 